\title{
Determinants of Fdi in China
}

\author{
Bhawana Miglani \\ Assistant Professor P.G.D.A.V. College, D.U.
}

\begin{abstract}
Foreign direct investment (FDI) is a direct investment into production or business in a country by a company in another country, either by buying a company in the target country or by expanding operations of an existing business in that country. China has become the second largest FDI recipient in the world, after the United States, and the largest host country among developing countries. Foreign direct investment (FDI) can play an important role in achieving rapid economic growth in developing countries. Developing countries have not been considered as favourable destinations for FDI as developed countries. Moreover, among the developing countries a few, such as China, India, Nigeria and Sudan, are the major recipients of FDI, with the rest vying for the scraps. This paper covers the FDI figures of China and how does FDI affect China and also the main determinants of FDI in China like size and growth of the Chinese economy and prospects, Natural and human resource endowments - cost and productivity of labour and Physical, financial and technological infrastructure.
\end{abstract}

Keywords: Endowments ,FDI, Financial and technological infrastructure, Prospects

\section{Introduction}

FDI has brought substantial and definite changes in China's external and internal economic structure. China has become the second largest FDI recipient in the world, after the United States, and the largest host country among developing countries. China's position as a host to FDI is in fact too far removed from any other developing country and to be equaled with most developed countries. Countries with larger GDPs, higher GDP growth rates, higher proportion of international trade and a more business-friendly environment are more successful in attracting FDI.

\section{Methodology}

Various secondary sources have been used in the writing of this paper.

\section{Results}

Following are the Figures displaying the inflow of FDI in China.

$\$ 306$ billion

1979-1999 (10 per cent of direct investment worldwide and about 30 per cent of the investment amount for all the developing countries put together)

$\$ 71.4$ billion

Jan-Jul 2013

$\$ 14.4$ billion

June 2013

$\$ 9.4$ billion

July 2013

$\$ 88.6$ billion

Jan-Sep 2013

$\$ 8.8$ billion

Sep 2013

China's "open door policy" launched twenty years ago contributed majorly to its growth in FDI.

The government issued a series of new policies and regulations to encourage FDI inflows.

Investors' future expectations about the Chinese economy in the manner similar to the vigorous growth rates of the early and mid-1990s have been the driving force behind FDI's spectacular growth in China.

\begin{tabular}{|l|l|l|l|}
\hline $\begin{array}{l}\text { Phase } \\
\text { (Years) }\end{array}$ & $\begin{array}{l}\text { FDI inflow } \\
\text { (US\$ million) }\end{array}$ & $\begin{array}{l}\text { Annual average } \\
\text { (US\$ million) }\end{array}$ & $\begin{array}{l}\text { Annual rate of increase } \\
(\%)\end{array}$ \\
\hline $\begin{array}{l}\text { First Phase } \\
(1979-1983)\end{array}$ & 1802 & 360 & 55.4 \\
Second Phase & & & 27.2 \\
$1984-1991$ & 21546 & 2693 & 38.1 \\
$1984-1988$ & 10301 & 2060 & 11.0 \\
$1989-1991$ & 11245 & 3748 & 32.1 \\
Third Phase & 282653 & 35331 & \\
$(1992-1999)$ & & & \\
\hline
\end{tabular}

Source: China Statistical Yearbook 
Overall, China has seen a twenty-fold increase in capital inflows from the early 1980s to 1998. The aggregate capital inflows into China grew steadily during the $1980 \mathrm{~s}$, but they have increased very rapidly since the early 1990s, caused overwhelmingly by the large inflows of FDI.

\section{Sources of FDI}

Hong Kong comes first as a single investor.

Asian investors were responsible for the bulk of the FDI, with the top Asian 10 nations accounting for 86 percent of total FDI in the first nine months, far outstripping U.S. firms, which accounted for 3.3 percent.

European firms were responsible for 6.7 percent of Chinese FDI.

Newly industrialised economies (NIEs) have been the largest investors as a group.

Four ASEAN countries (Thailand, Philippines, Malaysia, Indonesia) have substantially increased their presence in China since the early 1990s.

Among the developed countries, Japan and the United States have been the most important investors in China.

\section{Sectoral Distribution}

Manufacturing 60 per cent of the total contracted FDI by 1998.

Real estate 24.4 per cent

Distribution industry including transport, wholesale and retailing is 6.0 per cent.

Construction 3.1 per cent.

Primary industry such as agriculture, forestry and fishing 1.8 per cent.

Service trade, such as finances, telecommunications and wholesale and resale commerce, will take up a larger share as a result of Chinese accession to WTO and further liberalization.

\section{(1) Size and growth of the Chinese economy and prospects}

\section{Main determinants of FDI in China}

The general implication is that host countries with larger market size, faster economic growth and higher degree of economic development will provide more and better opportunities for the industries to exploit their ownership advantages and, therefore, will attract more FDI.

The market size of host countries is important because larger economies can provide larger economies of scale and spill-over effects.

China has a population of 1.2 billion, with a vast potential for consumption. Investors regard the Chinese market as the last enormous market that has not been developed in the whole world. Over the past decades or more, the scale of China's economic reconstruction has been expanding increasingly, with the purchasing power of the people strengthening rapidly and markets becoming increasingly brisk. The general implication is that host countries with larger market size, faster economic growth and higher degree of economic development will provide more and better opportunities for the industries to exploit their ownership advantages and, therefore, will attract more FDI.

China's rapid economic growth and continuously increased purchasing power has made China attractive to FDI.

\section{(2) Human resource endowments}

Labour force, land and natural resources are the important factors to attract FDI. The degree of development of host countries is often considered one of the most important determinants of FDI flows because it is positively related to domestic entrepreneurship, education level, and local infrastructure.

Chinese labourers are of relatively high quality and there are comparatively numerous technical personnel.

China is also very rich in energy reserve.

China is the largest producer of coal.

China's electric power supply is also experiencing an oversupply problem.

Other major natural resources such as land, iron and other minerals are economically available.

Especially, the expansion of FDI in agriculture will depend on the degree of opening up to the market circulation of agricultural products and the industrialised process of production operations.

\section{(3) Physical, financial and technological infrastructure}

It can be presumed that the availability of physical infrastructure affects the decision of selecting the investment place.

The more highways, railways and interior transport waterways are adjusted according to the size of host province, the more FDI inflows. 
Another important variable is the level of telecommunication services. Higher levels of telecommunications services will save time and reduce the costs of communication and information gathering, thus facilitating business activities.

In recent years, pushed by the market competition, the upgrading speed of China's industrial structure has been accelerated.

Especially, the development of high-tech has been greatly speeded up.

The current level of the technology of China and its provinces functions in order to attract FDI and induce the technology transfer.

\section{(4) Openness to international trade and access to international markets}

China has implemented economic reforms and open door policies and made efforts to promote trade by concluding several bilateral trade arrangements and adopted unilateral actions.

China has also formulated and implemented a series of preferential policies to encourage international trade.

Duty exemptions for intermediate products used in the production of exports have been particularly important in boosting China's foreign trade.

Chinese further acceptance of multilateral investment arrangement is necessary to promote FDI into China.

China's entry into the WTO will be conducive to the settlement of the problems.

In terms of accessibility to international markets, China has also some merit.

FDI use particular and specific resources at a lower real cost in foreign countries and then to export the output produced to the home country or to third countries.

China has a relatively attractive and strategic geographic position in that its territory is huge and offers access to other Asian countries and the Americas.

(5) Development of the regulatory framework and economic policy coherence

China has endeavoured to introduce a more transparent legal framework and business environment.

It has been streamlining its legal system concerning FDI.

China has amended a series of laws, regulations and provisions.

The Chinese policy to allow FDI seems to be on the right track.

China is most likely to maintain its economic growth policy.

\section{(6) Investment protection and promotion}

The law is viewed as a step in the right direction with regard to transparency and procedure.

The Chinese government adopted and implemented a series of new policies and regulations to encourage FDI inflows.

The incentives available include significant reductions in national and local income taxes, land fees, import and export duties, and priority treatment in obtaining basic infrastructure services.

To encourage reinvestment of profits, China has been offering FDI a refund of 40 per cent of taxes paid on its share of income, if the profit is reinvested in China for at least five years.

Where profits are reinvested in high-technology or export-oriented enterprises, the foreign investor may receive a full refund.

\section{Forms of investment}

(greenfield, acquisition, joint ventures, alliances, subcontracting, licensing)

The establishment of new enterprises such as new foreign funded and joint venture companies has been the main mode of absorbing FDI into China. During the period from 1979 to 1997, equity joint ventures took the lion's share of inward direct investment inflows (61.3 per cent in terms of the number of contracts and 46.0 per cent in terms of contracted amounts). Wholly foreign-owned enterprises took 24.7 per cent of FDI (in terms of the contract number and 30.0 per cent in terms of contracted amounts). Contractual joint ventures have been the third most important mode (14.0 per cent in terms of the numbers and 23.2 per cent in terms of the contracted amounts). As mergers and acquisitions have become the popular mode of global FDI with more than a 60 per cent share, this entry mode presents great potential for the future expansion of FDI in China. Also, the share of wholly foreign-owned enterprises is expected to increase as China implements its WTO commitments. Recent trends show that FDI tends to be more and more directed into wholly foreign-owned enterprises, which accounted for more than half of total commitments in 1999. 


\section{FDI in China}

\begin{tabular}{|l|l|l|l|l|l|l|l|l|l|l|l|l|}
\hline $\begin{array}{l}\text { Contracted } \\
\text { value }\end{array}$ & $\begin{array}{l}1979- \\
1989\end{array}$ & 1990 & 1991 & 1992 & 1993 & 1994 & 1995 & 1996 & 1997 & 1998 & 1999 \\
\hline Joint Ventures & 38.7 & 41.0 & 50.8 & 50.1 & 49.5 & 48.6 & 43.5 & 43.5 & 40.6 & 33.2 & 32.3 \\
\hline $\begin{array}{l}\text { Co-operative Joint- } \\
\text { Ventures }\end{array}$ & 41.9 & 19.0 & 17.8 & 22.8 & 22.9 & 24.6 & 19.5 & 19.5 & 23.7 & 22.4 & 16.5 \\
\hline $\begin{array}{l}\text { Wholly Foreign } \\
\text { Enterprises }\end{array}$ & 9.7 & 37.1 & 30.6 & 27.0 & 27.3 & 26.5 & 36.9 & 36.6 & 34.6 & 41.8 & 50.7 \\
\hline Others & 9.7 & 2.9 & 0.8 & 0.1 & 0.3 & 0.3 & 0.1 & 0.4 & 1.1 & 2.7 & 0.5 \\
\hline
\end{tabular}

Source: MOFTEC

\section{Benefits to China}

- FDI has been at the core of China's foreign trade expansion.

- FDI contributes to domestic capital formation. The ratio of FDI to GDP has increased from 0.31 per cent in 1983, to 1 per cent in 1991, 6.22 per cent in 1994, and staying around 5 per cent in the second half of 1990s.

- Both total employment and urban employment in FDI firms in China have increased significantly.

\section{Conclusion}

China's policy aimed at promoting FDI has led to the building of an internationalised manufacturing sector, highly competitive in world markets. The positive effect of China's opening up strategy was not so evident, however, for domestic firms, which recorded a relatively modest export performance. The internationalised sector also developed few backward and forward linkages with the rest of the economy. China's trade is likely to become less dependent on foreign firms as liberalisation will give more room to imports supplying the domestic market.

\section{References}

[1]. http://en.wikipedia.org/wiki/Foreign_direct_investment

[2]. http://www.info.com/foreign $\% 20$ direct $\% 20$ investment?cb $=79 \& \mathrm{cmp}=2850$

[3]. http://www.webcrawler.com/info.wbcrwl.305.03/search/web?q=foreign+direct+investment+fdi\&cid=126727024\&ad.network=s\&ad.k eyword=foreign $\% 20$ direct $\% 20$ investment $\% 20 f d i \&$ ad.creative=23578182304\&ad.position=1t $1 \&$ ad.placement=\&ad $. \mathrm{matchtype}=\mathrm{b} \& \mathrm{ad}$. aceid $=\&$ ad. ismobile $=\&$ ad.device $=c \&$ ad. devicemodel $=\&$ ad. .segment $=$ info. wbcrwl .305 .03

[4]. http://www.ask.com/web?qsrc=6\&o=10001184\&oo=102140\&l=dir\&qo=contentPageRelatedSearch\&ad=semA\&an=google_s\&ag=Jot -Im\&q=FDI+in+China

[5]. http://econpapers.repec.org/article/wsiceprxx/v_3a01_3ay_3a2012_3ai_3a01_3ap_3a1250003-1-1250003-15.htm 